\title{
Ethanol Oxidation and Toxicity: Role of Alcohol P-450 Oxygenase
}

\author{
Dennis R. Koop and Minor J. Coon
}

\begin{abstract}
The isolation and characterization of ethand-inducible rabbit liver microsomal cytochrome P-450, termed P-450 3a or P-450ALC, has provided definitive evidence for the rote of this enzyme in alcohol oxidation. From findings on the distribution, substrate specificity, and mechaniem of action of P-450ALC we have suggested "akchol P-450 oxygenase" as a more biochemically accurate name than "microsomal ethanol-oxidizing system." The present review is concerned with studies in this and other laboratories on activities and inducers associated with this versatile enzyme. Numerous xenobiotics, including alcohols and ketones, nitrosamines, aromatic compounds, and halogenated ankes, alkenes, and ethers, are known to undergo increased microsomal motabolism after chronic exposure of various species to ethanol. Diverse compounds and treatments may induce P-450ALC, including the administration of ten or more chemically different compounds, fasting, or the diabetic state. Whether a common mechanism of induction is involved is unknown of this time. As direct evidence that P-450ALC catalyzes numerous metabolic reactions, the purified rabbit enzyme has been used in a reconstfuted system to demonstrate various metabolic transformations, including the oxidation of various alcohols, acetone, acetol, pnitrophenol, and aniline, the dealkylation of substituted nitrosamines, the reductive dechlorination of carbon tetrachloride, carbon tetrachloride-induced lipid peroxidation, and acetaminophen activation to form the glutathione conjugate.
\end{abstract}

$\mathbf{E}$ THANOL consumption is known to have profound biochemical and physiological effects in animals and man.' The mechanisms by which ethanol perturbs cellular homeostasis are not yet well understood but appear to involve interactions with cellular and subcellular membranes ${ }^{2}$ as well as secondary changes resulting from ethanol metabolism. ${ }^{3.4}$ Considerable evidence exists that alcoholics have enhanced susceptibility to potential toxins, such as commonly used drugs and industrial solvents, which may be hepatotoxic, mutagenic, or carcinogenic. ${ }^{5-8}$ Most such compounds are not toxic or carcinogenic per se, but elicit their effects after metabolic activation by the cytochrome P-450-dependent mixed function oxidase system. ${ }^{9}$ Ethanol can both stimulate and inhibit P-450-de-

From the Depurtment of Biological Chemistry, Medical School. The Unvierstly of Michigan, Ann Arbor. Michigan.

Reccived for mublication March 3, 1986: accepted for publication March 11. 1986.

Preparation of this review was aided by Grants AA-06756 (DRK) and AA-0622I (MJC) from the National Instinute on Alcohol Ahuse and Alcoholism

Reprint requests. Dr. M. J. Coon. Department of Biological Chemistry: Medical Science I Bldg. Bnx 034. The University of Michigan. Ann Artor. MI 48109

Copyright (c. 1986 hy. The American Medical Suciety on Alcoholism and The Rescarch Society on A/coholism. pendent metabolism. The inhibitory effects of an acute dose are due, in part, to the ability of ethanol to bind to $\mathrm{P}-450$ isozymes and thus compete with the metabolism of other substrates. ${ }^{6.10}$ In addition, ethanol decreases the availability of NADPH. ${ }^{11,12}$ The stimulation of P-450. dependent metabolism by the chronic administration of ethanol, which can result from the induction of specific isozymes of cytochrome P-450, is the subject of this review.

The enzyme system primarily responsible for both the bioactivation and the inactivation of xenobiotics is the microsomal P-450-dependent mixed function oxidase system. ${ }^{13}$ The terminal oxidases of the system are collectively referred to as $\mathrm{P}-450$, although it has been clearly established that distinct isozymes of $P-450$ are present in hepatic as well as extrahepatic tissues. ${ }^{9.14-16}$ Each isozyme has a characteristic substrate preference although, in most cases, considerable overlap in metabolic activity exists. Until recently, it was difficult if not impossible to attribute an observed metabolic activity to a specific isozyme. However, the purification of individual P-450 isozymes has provided the necessary antigens for production of specific inhibitory monoclonal and polyclonal antibodies to be used in identifying the activities of each such catalyst. Each species has its own complement of P-450's, but recent comparisons of the primary structures by direct sequence analysis or by prediction from the cDNA structures indicate that homologous isozymes are present in different species. ${ }^{16.17}$ Structural homology is also evident from the cross-reactivity of monoclonal and polyclonal antibodies ${ }^{18.19}$ with the cytochromes from different organisms. Furthermore, the homologous isozymes in different species have very similar metabolic activities. For example, rat $P-450 c$, rabbit $P-4506$, and mouse $P_{1}-450$ are structurally and immunochemically similar and are the most active isozymes in the metabolism of benzo( $a$ ) pyrene. ${ }^{18.20}$ In addition, all three isozymes are induced by $2,3,7,8$-tetrachlorodibenzo-p-dioxin. ${ }^{21}$

The exposure of experimental animals and man to drugs and xenobiotics results in the induction of one or more isozymes of cytochrome P-450. ${ }^{17.22 .23}$ In the late 1960s and early 1970s, Lieber and coworkers reported that ethanol treatment of humans and rats resulted in proliferation of the hepatic smooth endoplasmic reticulum and an increase in the drug-metabolizing activity of microsomal preparations. ${ }^{24-26}$ These effects were accompanied by an increase in the microsomal P-450 concentration and 
an increase in the ability of hepatic microsomes to catalyze the oxidation of ethanol. ${ }^{27-30}$ The microsomal ethanoloxidizing activity was shown to be present in a $\mathrm{P}-450$ fraction by solubilization and reconstitution of components free of catalase and alcohol dehydrogenase. ${ }^{29,31-33}$ An observed increase in microsomal ethanol oxidation activity and a change in the banding pattern of hepatic microsomes on sodium dodecyl sulfate-polyacrylamide gels distinct from that produced by phenobarbital or 3methylcholanthrene led to the hypothesis that ethanol induced a unique isozyme of cytochrome P-450. ${ }^{29}, 34 \mathrm{De}$ finitive proof for the existence of a unique ethanol-inducible isozyme of cytochrome P-450 was provided by the purification and characterization of an isozyme from ethanol-treated rabbits, ${ }^{35.36}$ about 12 years after the effects of ethanol on P-450 were first documented.

Rubin et al. ${ }^{26}$ reported that, in addition to an increase in cytochrome $\mathrm{P}-450$, the microsomal $p$-hydroxylation of aniline was increased about 7 -fold by ethanol administration. The increase in aniline hydroxylation is an excellent marker for ethanol-dependent increases in P-450-dependent metabolism and is more reliable than measurement of ethanol oxidation due to lower blank values. Aniline hydroxylation is elevated $16-24 \mathrm{hr}$ after a single dose of ethanol ${ }^{37-39}$ or after vapor exposure, ${ }^{40}$ and is induced by ethanol even though no significant increase is seen in total $P-450$ in liver from rabbits ${ }^{36,41}$ and chick embryos. ${ }^{42}$ The metabolism of a large number of structurally diverse compounds, in addition to aniline and ethanol, is increased by ethanol consumption. Table 1 provides a partial list of compounds where in vitro metabolism and/or in vivo toxicity is enhanced by ethanol treatment. The list is not meant to be comprehensive but to provide representative examples. As can be seen, the reactions attributable to an ethanol-inducible isozyme include aromatic hydroxylation (aniline), aliphatic hydroxylation (acetone), dehalogenation (enflurane), $N$-demethylation ( $N$-nitrosodimethylamine), and alcohol oxidation (ethanol), all characterized as monooxygenase reactions of $\mathrm{P}-450.9 .72$

While all of the activities indicated above are induced by ethanol treatment, thus implicating an ethanol-inducible isozyme of P-450, many are also induced by other agents or treatments as summarized in Table 2. Such results bring to mind many possible interpretations, the simplest being either that each compound induces a unique isozyme that exhibits an overlapping substrate preference to that of other isozymes, or that all compounds induce the same isozyme, in this case the alcohol-inducible form. The availability of the purified ethanol-inducible isozyme $3 \mathrm{a}$ from rabbits, along with specific antibodies to this enzyme, has enabled us to test these two contrasting hypotheses. The direct structural comparison of the enzyme purified from ethanol-, imidazole-, and acetonetreated rabbits indicated that the same isozyme is induced by all three compounds. ${ }^{48.79 .93}$ Furthermore, an immunochemically identical isozyme is induced separately by
Table 1. Substrates That Undergo Increased Metabolism after Ethand Treatment of Animals

\begin{tabular}{|c|c|c|}
\hline Substrate tested & $\begin{array}{l}\text { Species } \\
\text { examined }\end{array}$ & References \\
\hline \multicolumn{3}{|l|}{ Acohols and ketones } \\
\hline \multirow[t]{4}{*}{ Ethand } & Rat & 27 \\
\hline & Rabbit & 36 \\
\hline & Hamster & 43 \\
\hline & Deormouse & 44.45 \\
\hline \multirow[t]{2}{*}{ Acetol } & Rat & 46,47 \\
\hline & Raboit & 48 \\
\hline \multirow[t]{2}{*}{ n-Propyl alconol } & Rat & 49 \\
\hline & Deermouse & 44 \\
\hline \multirow[t]{2}{*}{ n-Butyl alcohol } & Rat & 49 \\
\hline & Rabbit & 50 \\
\hline 2-Butand & Rat & 51 \\
\hline$n$-Pentanol & Rabbit & 50 \\
\hline \multirow[t]{2}{*}{ Acetone } & Rat & 46,47 \\
\hline & Rabbit & 48 \\
\hline \multicolumn{3}{|l|}{ Nitrosamines } \\
\hline \multirow[t]{2}{*}{ N-Nitrosodimethytamine } & Rat & $52-55$ \\
\hline & Rabbit & 56 \\
\hline \multirow[t]{2}{*}{ N-Nitrosopyrrolidine } & Rat & 57 \\
\hline & Hamster & 58 \\
\hline N-Nitroso-2,6-dimethylmorpholine & Raboit & 59 \\
\hline N-Nitrosonomicotine & Rat & 60 \\
\hline \multicolumn{3}{|l|}{$\begin{array}{l}\text { Halogenated akkanes, alkenes, and } \\
\text { ethers }\end{array}$} \\
\hline Enflurane & Rat & 61 \\
\hline Carbon tetrachioride & Rat & $54,62-64$ \\
\hline Chloroform & Rat & 63 \\
\hline Trichloroethylene & Rat & 63 \\
\hline 1,1-Dichioroethylene & Rat & 63 \\
\hline 1,2-Dichloroethane & Rat & 63 \\
\hline \multicolumn{3}{|l|}{ Aromatic compounds } \\
\hline \multirow[t]{4}{*}{ Aniline } & Rat & $26,31,40$ \\
\hline & Rabbit & 36 \\
\hline & Hamster & 43.65 \\
\hline & Mouse & 66 \\
\hline \multirow[t]{3}{*}{ Acetaminophen } & Rat & 67 \\
\hline & Mouse & 68.69 \\
\hline & Hamster & 65 \\
\hline Benzene & Rat & 63 \\
\hline Toluene & Rat & 63 \\
\hline \multirow[t]{2}{*}{ p-Nitrophenol } & Rat & 70,71 \\
\hline & Rabbit & \\
\hline
\end{tabular}

trichloroethylene, isoniazid, benzene, pyrazole, acetone, and imidazole in this species. ${ }^{48.79}$ Thus, the results strongly suggest that these structurally diverse compounds induce the same isozyme.

Antibody inhibition in conjunction with reconstitution experiments demonstrated the role of $P-450$ isozyme $3 a$ in microsomal preparations. The reactions catalyzed by this cytochrome in rabbit microsomes are shown in Table 3. It is important to emphasize that for most of the reactions isozyme $3 a$ is not the sole catalyst, since other isozymes are known to exhibit significant activity. However, the results of antibody inhibition experiments indjcate that, after ethanol treatment, isozyme $3 a$ is the principal catalyst. For example, anti-3a lgG inhibits $90 \%$ of the $N$-nitrosodimethylamine demethylase activity, $75 \%$ of the ethanol oxidation activity, and $60 \%$ of the aniline hydroxylase activity of microsomes from ethanol-treated rabbits, and this antibody inhibits $70 \%, 35 \%$, and $30 \%$ of the respective activities in microsomes from untreated rabbits. ${ }^{50.75}$ Since other isozymes exhibit significant activ- 
Table 2. Agents or Treatments Having Inducing Effects Similar to That of Ethanol

\begin{tabular}{|c|c|c|c|}
\hline $\begin{array}{l}\text { Treatment or } \\
\text { inducer } \\
\text { administered to } \\
\text { animal }\end{array}$ & $\begin{array}{l}\text { Substrate examined } \\
\text { for activity } \\
\text { of microsomes }\end{array}$ & $\begin{array}{l}\text { Species } \\
\text { examined }\end{array}$ & Reference \\
\hline \multirow[t]{6}{*}{ Acelone } & N-Nitrosodimeth- & Rat & 73,74 \\
\hline & ylamine & Gunea pig & 75 \\
\hline & n-Butyl alcohol & Rabbit & 41 \\
\hline & Acetone & Rat & 46 \\
\hline & Acetone & Rabbit & 48 \\
\hline & $\begin{array}{l}\text { Carbon tetrachio- } \\
\text { ride }\end{array}$ & Rat & 76 \\
\hline \multirow[t]{4}{*}{ Pyrazole } & $\begin{array}{l}\text { N-Nitrosodimeth- } \\
\text { ylamine }\end{array}$ & Rat & 77,78 \\
\hline & $\begin{array}{l}\text { n-Butyl alcohol. } \\
\text { anitine }\end{array}$ & Rabbit & 41.79 \\
\hline & 2-Butanol & Rat & 80,81 \\
\hline & $\begin{array}{l}\text { Carbon tetrachilo } \\
\text { ride }\end{array}$ & Rabbit & 82 \\
\hline \multirow[t]{3}{*}{ Isopropyl alcohol } & $\begin{array}{l}\text { N-Nitrosodimeth- } \\
\text { ylamine }\end{array}$ & Rat & 73,74 \\
\hline & $\begin{array}{l}\text { Carbon tetrachio- } \\
\text { ride }\end{array}$ & Rat & 83,84 \\
\hline & Anitine & Rat & 84 \\
\hline 4-Methylpyrazole & 2-Butanol & Rat & 80 \\
\hline \multirow[t]{3}{*}{ Imidazole } & Aniline & Rabbit & 79 \\
\hline & n-Butyt atconol & Rabbit & 41 \\
\hline & $\begin{array}{l}\text { N-Nitrosodimeth- } \\
\text { Ylamine }\end{array}$ & Rabbit & 85 \\
\hline Fasting & $\begin{array}{l}N \text {-Nitrosodimeth } \\
\text { ylamine }\end{array}$ & Rat & 86 \\
\hline Trichioroethylene & n-Butyt alconol & Rabbrt & 41 \\
\hline Benzene & Aniline & Rabbit & 87 \\
\hline \multirow[t]{2}{*}{ Diabetic state } & Anitine & Rat & 88 \\
\hline & $\begin{array}{l}N \text {-Nitrosodimeth- } \\
\text { ylamine }\end{array}$ & Rat & 89 \\
\hline \multirow[t]{3}{*}{ Isoniazid } & Anitine & Rat & 90.91 \\
\hline & Enfiurane & Rat & 90 \\
\hline & n-Butyl alconol & Rabort & 41 \\
\hline $\begin{array}{l}\text { Ethylere thi- } \\
\text { ourea }\end{array}$ & Aniline & Mouse & 92 \\
\hline
\end{tabular}

Table 3. Reactions Catalyzed by Rabbit Lver Microsomal P-450 isozyme $3 a$

\begin{tabular}{lc}
\multicolumn{1}{c}{ Reaction catalyzed } & References \\
\hline N-Nitrosodimethylamine demethylation $\left(\right.$ low $K_{m}$ ) & 56,75 \\
Accohol oxidation (ethand, butanol. and pentanol) & 50 \\
Acetone hydroxylation & 48 \\
Acetol oxidation & 48 \\
p-Nitrophenol hydroxylation & 94 \\
Aniline hydroxylation & 50 \\
Carbon tetrachlonde reductive dechlorination & 82 \\
N-Nitroso-2.6-dimethylmorpholine hydroxylation & 59 \\
Carbon tetrachioride-induced lipid peroxidation & 82 \\
Acetaminophen activation (to torm glutathione conjugate) & 95
\end{tabular}

ity toward some substrates, the induction of a particular microsomal activity does not necessarily mean that the level of isozyme 3a has been increased; such a conclusion requires confirmation by antibody inhibition. The effect of substrate concentration is also a highly important consideration in an evaluation of the relative roles of different isozymes, as strikingly demonstrated with $N$-nitrosodimethylamine. Ethanol and certain other compounds induce a demethylase with a low $K_{m}$ for this substrate in rats $^{52.53}$ and rabbits. ${ }^{56}$ Of six rabbit isozymes tested, only 3a exhibited activity with $0.1 \mathrm{~mm} N$-nitrosodimethylamine, whereas isozymes $2,3 \mathrm{a}, 3 \mathrm{~b}, 3 \mathrm{c}$, and 6 displayed activity with $4 \mathrm{~mm}$, and all six isozymes were active, with isozyme $3 \mathrm{a}$ being only slightly more effective than isozyme 6 , at the highest substrate concentration, $100 \mathrm{~mm}$. Thus, depending upon the substrate concentration, isozyme 3a could be the sole catalyst or one of numerous isozymes effecting the demethylation reaction. This cytochrome appears to be the sole catalyst for acetone hydroxylation since the antibody inhibited $90 \%$ or more of the activity in microsomes from both untreated and ethanol-treated rabbits. ${ }^{48}$ Similar results have recently been obtained for the hydroxylation of $p$-nitrophenol to give 4-nitrocatechol. ${ }^{94}$

The antibody to rabbit isozyme 3a was also shown to be inhibitory in microsomes from other species, suggesting the presence of a homologous isozyme. The antibody inhibited $71 \%$ and $92 \%$ of the $N$-nitrosodimethylamine demethylase activity of microsomes from untreated and ethanol-treated rats, respectively, at $5 \mathrm{~mm}$ substrate. ${ }^{75} \mathrm{Tu}$ and Yang ${ }^{96}$ have recently reported that an isozyme termed P-450et from ethanol-treated rats has significant activity toward $N$-nitrosodimethylamine. Anti-3a IgG also was an effective inhibitor of acetone hydroxylation by microsomes from acetone-treated rats ${ }^{48}$ and of $N$-nitrosodimethylamine demethylation by microsomes from untreated mice and guinea pigs and acetone-treated guinea pigs, ${ }^{75}$ thus indicating the likely presence of a homologous isozyme in these species.

Ryan et al. ${ }^{91}$ reported the isolation from isoniazidtreated rats of $P-450 \mathrm{j}$, a cytochrome with activity in aniline hydroxylation and spectral properties similar to those of rabbit isozyme 3a. As a further similarity, the first 19 residues of the amino terminus of $\mathrm{P}-450 \mathrm{j}$ exhibit $68 \%$ sequence homology with isozyme $3 \mathrm{a}$, which is also known to be induced by isoniazid. ${ }^{4}$ We have exchanged purified proteins and antibody with Ryan and co-workers and found that, in all respects, $\mathrm{P}-450 \mathrm{j}$ and isozyme $3 \mathrm{a}$ are highly similar enzymes. ${ }^{97}$ The degree of structural homology can be determined only when the complete amino acid sequences are known.

The immunochemical and structural comparison of P$450 \mathrm{j}$ and isozyme $3 \mathrm{a}$ and the results of antibody inhibition experiments suggest that ethanol, isoniazid, and acetone induce $\mathrm{P}-450 \mathrm{j}$ and isozyme $3 \mathrm{a}$, as indicated above, and that a homologous isozyme is induced by acetone in guinea pigs. ${ }^{75.97}$ However, compounds that induce isozyme $3 a$ in rabbits need not necessarily have comparable effects in other species, as shown by the following examples. Reinke et al. ${ }^{71}$ reported that, in the rat, imidazole treatment resulted in an increase in 7-ethoxycoumarin deethylation and aminopyrine demethylation with no ac- 
companying increase in aniline hydroxylation or p-nitrophenol hydroxylation. The protein profiles on sodium dodecyl sulfate-polyacrylamide gels also suggested marked differences in induction by imidazole or ethanol. Pyrazole induces isozyme $3 \mathrm{a}$ in rabbits ${ }^{41}$ and $N$-nitrosodimethylamine demethylation ${ }^{77.78}$ and alcohol oxidation activities in rats. ${ }^{80}$ In contrast, in three strains of mice, $\mathrm{DBA} / 2 \mathrm{~N}$, $\mathrm{C} 57 \mathrm{BL} / 6 \mathrm{~N}$, and $\mathrm{AKR} / \mathrm{N}$, pyrazole had no effect on $N$ nitrosodimethylamine demethylation, while coumarin 7hydroxylase activity was induced in the DBA/2 strain only. ${ }^{98}$ Furthermore, Elves et al. ${ }^{66}$ reported that ethanol treatment induces aniline hydroxylation in $\mathrm{C} 57 \mathrm{BL} / 6 \mathrm{~J}$ and $\mathrm{A} / \mathrm{J}$ mice. The results of such experiments indicate that the effect of an administered agent is both species- and strain-dependent, and that more than one isozyme may be induced. Feierman and Cederbaum ${ }^{80}$ have recently compared the inductive effects of pyrazole and 4-methylpyrazole in rats. Pyrazole treatment had no effect on total microsomal $\mathrm{P}-450$ or aminopyrine demethylation, while 4-methylpyrazole treatment resulted in about a 2-fold increase in both as well as an increase in the microsomal rates of ethanol and 2-butanol oxidation. These results are suggestive that, in the rat, 4-methylpyrazole treatment results in the induction of more than one P-450 isozyme.

At the present time the available evidence indicates that ethanol induces a single isozyme in hepatic microsomes from rabbits. However, until all of the isozymes present in the microsomal fraction have been purified and characterized, the coinduction of other cytochromes cannot be excluded. There is suggestive evidence that ethanol-treatment may induce other isozymes in extrahepatic tissues. Rat $P-450 \mathrm{j}$ has no significant activity toward benzo( $a$ ) pyrene, ${ }^{91}$ yet Lieber and co-workers reported that chronic ethanol treatment significantly enhanced 3-hydroxybenzo $(a)$ pyrene formation in microsomes from rat intestinal mucosa. ${ }^{99}$ These results may be taken to mean that either a different isozyme is induced by ethanol in the intestinal mucosa or that the effect of ethanol is to stimulate in some manner constitutive isozymes that hydroxylate benzo( $a$ )pyrene. Ethanol treatment was reported to have no effect on lung microsomal benzo( $a$ )pyrene metabolism, although the activation of tobacco smoke condensate was enhanced. ${ }^{100}$ Ding et al. (X. Ding, D. R. Koop, B. L. Crump, and M. J. Coon, unpublished results) have examined a variety of extrahepatic rabbit tissues for the presence of isozyme $3 \mathrm{a}$, which was identified by immunoblots in microsomes from the kidney and nasal membranes; the enzyme was induced by ethanol in the former but not the latter tissue. Due to species differences in the inducibility of this isozyme, it will be necessary to determine whether the enzyme is induced extrahepatically in the rat, as possibly indicated from mutagenesis studies. ${ }^{99.100}$

Much progress has been made toward an understanding of the effects of ethanol on P-450 since the initial observations of Lieber and coworkers in 1968. In addition to ethanol, a large number of other chemical agents have a similar effect on the P-450 system. Although the mechanisms by which such structurally diverse compounds induce one or more P-450 isozymes in a species- and tissuespecific manner remain to be elucidated, it has become clear that a particular ethanol-inducible isozyme is responsible for the metabolism and activation of many foreign compounds.

\section{REFERENCES}

1. Majchrowicz E, Nobel EP (eds): Biochemistry and Pharmacology of Ethanol, vols 1 and 2. New York, Raven Press, 1979

2. Sun GY, Sun AY: Ethanol and membrane lipids. Alcohol Clin Exp Res 9:164-180, 1985

3. Lieber CS: Metabolism and metabolic effects of alcohol. Med Clin North Am 68:3-31, 1984

4. Veech RL, Felver ME, Lakshmanan MR, Huang, M-T: Control of a secondary pathway of ethanol metabolism by differences in redox state: A study of the failure to arrest the Krebs cycle for drunkenness. Curr Top Cell Regul 18:151-179, 1981

5. Lieber CS, Seitz HK, Garro AJ, Worner TM: Alcohol-related diseases and carcinogenesis. Cancer Res 39:2863-2886, 1979

6. Pelkonen $\mathrm{O}$, Sotaniemi E: Drug metabolism in alcoholics. J Pharmacol Exp Ther 16:261-268, 1982

7. Tuyns AJ: Epidemiology of alcohol and cancer. Cancer Res 39:2840-2843, 1979

8. Lieber CS: Alcohol and the liver: 1984 update. Hepatology 4:1243-1260, 1984

9. Guengerich FP, Liebler DC: Enzymatic activation of chemicals to toxic metabolites. CRC Crit Rev Toxicol 14:259-307, 1985

10. Lieber CS: Interaction of ethanol with drug toxicity. Am J Gastroenterol 74:313-321, 1980

11. Reinke LA, Kauffman FC, Belinsky SA, Thurman RG: Interactions between ethanol metabolism and mixed-function oxidation in perfused rat liver. inhibition of $p$-nitroanisole O-demethylation.J Pharmacol Exp Ther 213:70-78, 1980

12. Reinke LA, Kauffman FC, Thurman RG: Stimulation of $p$ nitroanisole O-demethylation in perfused livers by xylitol and sorbitol. Biochem Pharmacol 29:813-819, 1980

13. Wislocki PG. Miwa GT. Lu AYH: Reactions catalyzed by the cytochrome P-450 system, in Jakoby WB (ed): Enzymatic Basis of Detoxication, vol 1. New York, Academic Press, 1980, pp 136-170

14. Coon MJ, Koop DR: P-450 oxygenases in lipid transformation, in Boyd P(ed): The Enzymes, vol 16. New York, Academic Press, 1983, pp 645-677

15. Lu AYH. West SB: Multiplicity of mammalian microsomal cytochromes P-450. Pharmacol Rev 31:277-295, 1980

16. Black SD, Coon MJ: Comparative structures of P-450 cytochromes, in Ortiz de Montellano P (ed): Cytochrome P-450. New York. Plenum Press, 1986, pp 161-216

17. Adesnik $M$, Atchison $M$ : Genes for cytochromes $P-450$ and their regulation. CRC Crit Rev Biochem 19:247-305, 1986

18. Thomas PE, Reidy J, Reik LM, Ryan DE, Koop DR, Levin W: Use of monoclonal antibody probes against rat hepatic cytochromes $P$. $450 \mathrm{c}$ and $\mathrm{P}-450 \mathrm{~d}$ to detect immunochemically related isozymes in liver microsomes from different species. Arch Biochem Biophys 235:239-252, 1984

19. Reik LM, Levin W, Ryan DE, Maines SL, Thomas PE: Monoclonal antibodies distinguish among isozymes of the cytochrome $P-450 \mathrm{~b}$ subfamily. Arch Biochem Biophys 242:365-382, 1985

20. Okino ST, Quattrochi LC, Barnes HJ, Osanto S, Griffin KJ, Johnson EF, Tukey RH: Cloning and characterization of CDNAs encoding 2,3,7,8-tetrachlordibenzo-p-dioxin-inducible rabbit mRNAs for $c y$ tochrome P-450 isozymes 4 and 6. Proc Natl Acad Sci USA 82:5310 5314. 1985 
21. Kimura S, Gonzales FJ. Neber DW: The murine Ah locus. Comparison of the complete cytochrome $P_{1}-450$ and $P_{3}-450$ cDNA nucleotide and amino acid sequences. $J$ Biol Chem 259:10705-10713, 1984

22. Neber DW. Gonzalez FJ: Cyrochrome P-450 gene expression and regulation. Trends Pharmacol Sci 6:160-164, 1985

23. Nebern DW, Eisen HJ, Negishi M, Lang MA, Hjelmeland LM: Genetic mechanisms controlling the induction of polysubstrate monooxygenase (P-450) activities. Annu Rev Pharmacol Toxicol 21:431-462, 1981

24. Iseri OA. Lieber CS, Gottlieb LS: The ultrastructure of fatty liver induced by prolonged ethanol ingestion. Am J Pathol 48:535-555, 1966

25. Rubin E. Lieber CS: Hepatic microsomal enzyme in man and rat: induction and inhibition by ethanol. Science 162:690-691, 1968

26. Rubin E, Hutterer F, Lieber CS: Ethanol increases hepatic smooth endoplasmic reticulum and drug-metabolizing enzymes. Science 159:1469-1470. 1968

27. Lieber CS, DeCarli LM: Ethanol oxidation by hepatic microsomes: adaptive increase after ethanol feeding. Science 162:917-918, 1968

28. Lieber CS. DeCarli LM: Hepatic ethanol-oxidizing system: in vitro characteristics and adaptive properties in vivo. J Biol Chem 245:2505-2512. 1970

29. Ohnishi K. Lieber CS: Reconstitution of the microsomal ethanol-oxidizing system (MEOS): qualitative and quantitative changes of cytochrome P450 after chronic ethanol consumption. J Biol Chem 252:7124-7131. 1977

30. Ishii H. Joly J-G. Lieber CS: Effect of ethanol on the amount and enzyme activities of hepatic rough and smooth microsomal membranes. Biochim Biophys Acta 291:411-420, 1973

31. Mezey E, Potter JJ, Reed WD: Ethanol oxidation by a component of liver microsomes rich in cytochrome P-450. J Biol Chem 248:1183-1187, 1973

32. Teschke R. Hanumara Y, Joly J-G, Lieber CS: Microsomal ethanol-oxidizing system (MEOS): purification and properties of a rat liver system free of catalase and alcohol dehydrogenase. Biochem Biophys Res Commun 49:1187-1193,1972

33. Teschke R, Hasumura $Y$, Lieber CS: Hepatic microsomal ethanol-oxidizing system: solubilization, isolation, and characterization Arch Biochem Biophys 163:404-415, 1974

34. Sharma RN, Cameron RG, Farber E, Griffin MJ, Joly J-G. Murray RK: Multiplicity of induction patterns of rat liver microsomal mono-oxygenases and other polypeptides produced by administration of various xenobiotics. Biochem J 182:317-327, 1979

35. Koop DR. Morgan ET. Tarr GE, Coon MJ: Purification and characterization of a unique isozyme of cytochrome P-450 from liver microsomes of ethanol-treated rabbits. J Biol Chem 257:8472-8480, 1982

36. Morgan ET, Koop DR, Coon MJ: Catalytic activity of cytochrome P-450 isozyme 3a isolated from liver microsomes of ethanoltreated rabbits. J Biol Chem 257:13951-1 3957, 1982

37. Ariyoshi T. Takashatake E, Remmer H: Drug metabolism in ethanol-induced fatty liver. Life Sci 9:361-369, 1970

38. Powis G: Effect of a single oral dose of ethanol and propan-2-ol on the hepatic microsomal metabolism of foreign compounds in rat. Biochem J 148:269-277, 1975

39. Liu S-J. Ramsey RK. Fallon HJ: Effect of ethanol on hepatic microsomal drug-metabolizing enzymes in rat. Biochem Pharmacol 24:369-378, 1975

40. Morgan ET. Devine $M$. Skett $P$ : Changes in the rat hepatic mixed function oxidase system associated with chronic ethanol vapor inhalation. Biochem Pharmacol 30:595-600, 198

41. Koop DR. Crump BL, Nordblom GD, Coon MJ: Immunochemical evidence for induction of the alcohol-oxidizing cytochrome P. 450 of rabbit liver microsomes by diverse agents: ethanol, imidazole, trichloroethylene, acetone, pyrazole, and isoniazid. Proc Natl Acad Sci USA $82: 4065-4069.1985$
42. Burnet R, Darby N: Ethanol induces an aniline hydroxylase in chick embryo liver without inducing cytochrome P-450. Biochem Soc Trans 12:686, 1984

43. McCoy GD: Differential effects of ethanol and other inducers of drug metabolism on the two forms of hamster liver microsomal aniline hydroxylase. Biochem Pharmacol 29:685-688, 1980

44. Burnett KG, Felder MR: Ethanol metabolism in Peromyscus genetically deficient in alcohol dehydrogenase. Biochem Pharmacol 29:125-130, 1980

45. Shigeta Y, Nomura F, lida S, Leo MA, Felder MR, Lieber CS Ethanol metabolism in vivo by the microsomal ethanol-oxidizing system in deermice lacking alcohol dehydrogenase (ADH). Biochem Pharmacol 33:807-814, 1984

46. Casazza JP, Felver ME, Veech RL: The metabolism of acetone in rat. J Biol Chem 259:231-236, 1984

47. Casazza JP, Veech RL: The production of 1,2-propanediol in ethanol-treated rats. Biochem Biophys Res Commun 129:426-430, 1985

48. Koop DR. Casazza JP: Identification of ethanol inducible P-450 isozyme $3 \mathrm{a}$ as the acetone and acetol monooxygenase of rabbit microsomes. J Biol Chem 260:13607-13612, 1985

49. Teschke R, Hasumura Y, Lieber CS: Hepatic microsomal alcohol-oxidizing system. Affinity for methanol, ethanol, propanol and butanol. J Biol Chem 250:7397-7404, 1975

50. Koop DR, Nordblom GD, Coon MJ: Immunochemical evidence for a role of cytochrome $\mathrm{P}-450$ in liver microsomal ethanol oxidation. Arch Biochem Biophys 235:228-238, 1984

51. Krikun G, Cederbaum Al: Sterochemical studies on the cytochrome P-450 and hydroxyl radical dependent pathways of 2-butanol oxidation by microsomes from chow-fed, phenobarbital-treated and ethanol-treated rats. Biochemistry 23:5489-5494, 1984

52. Garro AJ, Seitz HK, Lieber CS: Enhancement of dimethylnitrosamine metabolism and activation to a mutagen following chronic ethanol consumption. Cancer Res 41:120-124, 1981

53. Peng R, Tu YY, Yang CS: The induction and competitive inhibition of a high affinity microsomal nitrosodimethylamine demethylase by ethanol. Carcinogenesis 3:1457-1461, 1982

54. Maling HM, Stripp B, Sipes IG, Highman B, Saul W, Williams MA: Enhanced hepatotoxicity of carbon tetrachloride, thioacetamide and dimethylnitrosamine by treatment of rats with ethanol and some comparisons with potentiation by isopropanol. Toxicol Appl Pharmacol 33:291-308, 1975

55. Olson MJ, Pounds JG, Casciano DA: Potentiation of dimethylnitrosamine genotoxicity in rat hepatocyte isolated following ethanol treatment in vivo. Chem Biol Interact 50:313-326, 1984

56. Yang CS, Tu YY, Koop DR, Coon MJ: Metabolism of nitrosamines by purified rabbit liver cytochrome P.450 isozymes. Cancer Res 45:1140-1145, 1985

57. Farinati F, Zhou Z, Bellah J, Lieber CS, Garro AJ: Effect of chronic ethanol consumption on activation of nitrosopyrrolidine to a mutagen by rat upper alimentary tract, lung, and hepatic tissue. Drug Metab Dispos 13:210-214, 1985

58. McCoy D, Chen CB, Hecht SS, McCoy EC: Enhanced metabolism and mutagenesis of nitrosopyrrolidine in liver fractions isolated from chronic ethanol-consuming hamsters. Cancer Res 39:793-796, 1979

59. Kokkinakis DM, Koop DR, Scarpelli DG, Coon MJ, Hollenberg PF: Metabolism of $N$-nitroso-2,6-dimethylmorpholine by isozymes of rabbit liver microsomal cytochrome P-450. Cancer Res 45:619-624. 1985

60. Castonguay A, Rivenson A, Trushin N, Reinhardt J, Spathopoulos S, Weiss CJ, Reiss B, Hecht SS: Effect of chronic ethanol consumption on the metabolism and carcinogenicity of $N$-nitrosonomicotine in F344 rats. Cancer Res 44:2285-2290, 1984

61. Pantuck EJ, Pantuck CB, Ryan DE, Conney AH: Inhibition and stimulation of enflurane metabolism in the rat following a single dose or chronic administration of ethanol. Anesthesiology 62:255-262, 1985

62. Hasumura Y, Teschke R, Lieber CS: Increased carbon tetrachlo- 
ride hepatotoxicity, and its mechanism, after chronic ethanol consumption. Gastroenterology 66:415-422, 1974

63. Sato A. Nakajima T: Enhanced metabolism of volatile hydrocarbons in rat liver following food deprivation, restricted carbohydrate intake. and administration of ethanol, phenobarbital, polychlorinated biphenyl and 3-methylcholanthrene: a comparative study. Xenobiotica $15: 67-75,1985$

64. Traiger GJ, Plaa GL: Differences in the potentiation of carbon tetrachloride in rats by ethanol and isopropanol pretreatment. Toxicol Appl Pharmacol 20:105-112, 1971

65. Elliott CR, Prasad JS, Husby AD, Ellingson RJ, Holtzman JL, Crankshaw DL: Effects of chronic ethanol consumption on male syrian hamster hepatic microsomal mixed-function oxidases. Alcohol 2:17-22, 1985

66. Elves RG, Ueng T-H, Alvares AP: Comparative effects of ethanol administration on hepatic monooxygenases in rats and mice. Arch Toxicol 55:258-264, 1984

67. Sato C, Matsuda Y, Lieber CS: Increased hepatotoxicity of acetaminophen after chronic ethanol consumption in the rat. Gastroenterology 80:140-148, 1981

68. Walker RM, McElligott TF, Power EM, Massey TE, Racz WJ: Increased acetaminophen-induced hepatotoxicity after chronic ethanol consumption in mice. Toxicology 28:193-206, 1983

69. Peterson FJ, Holloway DE, Erickson RR, Duquette PH, McClain CJ, Holtzman JL: Ethanol induction of acetaminophen toxicity and metabolism. Life Sci 27:1705-1711, 1980

70. Reinke LA, Moyer MJ: p-Nitrophenol hydroxylation: a microsomal oxidation which is highly inducible by ethanol. Drug Metab Dispos 13:548-552. 1985

71. Reinke LA, Sexter SH, Rikans LE: Comparison of ethanol and imidazole pretreatments on hepatic monooxygenase activities in rat. Res Commun Chem Pathol Pharmacol 47:97-106, 1985

72. Guengerich FP, MacDonald TL: Chemical mechanisms of catalysis by cytochrome P-450. Acc Chem Res 17:9-16, 1984

73. Tu YY, Peng R, Chang Z-F. Yang, CS: Induction of a high affinity nitrosamine demethylase in rat liver microsomes by acetone and isopropanol. Chem Biol Interact 44:247-260, 1983

74. Sipes IG, Stripp B, Krishna G. Maling HM, Gillette JR: Enhanced hepatic microsomal activity by pretreatment of rats with acetone or isopropanol. Proc Soc Exp Biol Med 142:237-240, 1973

75. Yang CS, Koop DR, Wang T, Coon MJ: Immunochemical studies on the metabolism of nitrosamines by ethanol-inducible cytochrome P-450. Biochem Biophys Res Commun 128:1007-1014, 1985

76. Charbonneau M. lijima M. Cóté MG, Plaa GL: Temporal analysis of rat liver injury following potentiation of carbon tetrachloride hepatotoxicity with ketonic or ketogenic compounds. Toxicology 35:95112. 1985

77. Evarts PP. Haliday E. Negishi M, Hjelmeland LM: Induction of microsomal dimethylnitrosamine demethylase by pyrazole. Biochem Pharmacol 31:1245-1249, 1982

78. Tu YY. Sonnenberg J, Lewis KF, Yang CS: Pyrazole-induced cytochrome P-450 in rat liver microsomes: an isozyme with high affinity for dimethylnitrosamine. Biochem Biophys Res Commun 103:905-912, 1981

79. Ingelman-Sundberg $M$, Jörnvall $\mathrm{H}$ : Induction of ethanol-inducible form of rabbit liver microsomal cylochrome $P-450$ by inhibitors of alcohol dehydrogenase. Biochem Biophys Res Commun 124:375-382, 1984

80. Feierman DE, Cederbaum AI: Interaction of pyrazole and 4 methylpyrazole with hepatic microsomes: effect on cytochrome P-450 content. microsomal oxidation of alcohols and binding spectra. Alcohol Clin Exp Res 9:421-428. 1985
81. Krikun G, Cederbaum AI: Increased microsomal oxidation of alcohols after pyrazole treatment and its similarities to the induction by ethanol consumption. Biochim Biophys Acta 801:131-137, 1984

82. Johansson I, Ingelman-Sundberg $\mathbf{M}$ : Carbon tetrachloride-induced lipid peroxidation dependent on ethanol-inducible form of rabbit liver microsomal cytochrome P-450. FEBS Lett 183:265-269, 1985

83. Harris RN, Anders MW: 2-Propanol treatment induces selectively the metabolism of carbon tetrachloride to phosgene. Drug Metab Dispos 9:551-556, 1981

84. Ueng TH, Moore L, Elves RG, Alvares A: Isopropanol enhancement of cytochrome P450-dependent monooxygenase activities and its effects on carbon tetrachloride intoxication. Toxicol Appl Pharmacol 71:204-214, 1983

85. Kaul KL, Novak RF: Induction of rabbit hepatic microsomal cytochrome $P-450$ by imidazole: enhanced metabolic activity and altered substrate specificity. Arch Biochem Biophys 235:470-481, 1984

86. Tu YY, Yang CS: High affinity nitrosamine dealkylase system in rat liver microsomes and its induction by fasting. Cancer Res 43:623629,1983

87. Ingelman-Sundberg $M$, Hagbjörk AL: On the significance of the cytochrome P-450-dependent hydroxyl radical-mediated oxygenation mechanism. Xenobiotica 12:673-686, 1982

88. Past MR, Cook DE: Effect of diabetes on rat liver cytochrome P-450: evidence for a unique diabetes-dependent rat liver cytochrome P450. Biochem Pharmacol 31:3329-3334, 1982

89. Peng R, Tannant P, Lorr NA, Yang CS: Alterations of microsomal monooxygenase system and carcinogen metabolism by streptozotocin-induced diabetes in rats. Carcinogenesis 4:703-708, 1983

90. Rice SA, Talcott RE: Effects of isoniazid treatment on seiected mixed function oxidases. Drug Metab Dispos 7:260-262, 1979

91. Ryan DE, Ramanathan L, Iida S, Thomas PE, Haniu M, Shively JE, Lieber CS, Levin W: Characterization of a major form of rat hepatic microsomal cytochrome P-450 induced by isoniazid. J Biol Chem 260:6385-6393. 1985

92. Lewerenz HL, Plass R: Contrasting effects of ethylenethiourea on hepatic monooxygenases in rats and mice. Arch Toxicol 56:92-95, 1984

93. Koop DR, Coon MJ: Purification of liver microsomal cytochrome P-450 isozymes $3 \mathrm{a}$ and 6 from imidazole-treated rabbits: evidence for the identity of isozyme $3 \mathrm{a}$ with the form obtained by ethanol treatment. Mol Pharmacol 25:494-501, 1984

94. Koop DR: Hydroxylation of $p$-nitrophenol by rabbit ethanolinducible cytochrome P-450 isozyme 3a. Mol Pharmacol 29:399-404, 1986

95. Morgan ET, Koop DR, Coon MJ: Comparison of six rabbit liver cytochrome $\mathrm{P}-450$ isozymes in formation of a reactive metabolite of acetaminophen. Biochem Biophys Res Commun 112:8-13, 1983

96. Tu YY, Yang CS: Demethylation and denitrosation of nitrosamines by cytochrome P-450 isozymes. Arch Biochem Biophys 242:3240,1985

97. Ryan DE, Koop DR, Thomas PE, Coon MJ, Levin W: Evidence that isoniazid and ethanol induce the same microsomal cytochrome P450 in rat liver, an isozyme homologous to rabbit liver cytochrome $P$ 450 isozyme 3a. Arch Biochem Biophys 246:633-644, 1986

98. Juvonen RO, Kaipainen PK, Lang MA: Selective induction of coumarin 7-hydroxylase by pyrazole in D2 mice. Eur J Biochem 152:38,1985

99. Seitz HK, Garro AJ, Lieber CS: Effect of chronic ethanol ingestion on intestinal metabolism and mutagenicity of benzo( $\alpha)$ pyrene. Biochem Biophys Res Commun 85:1061-1066, 1978

100. Seitz HK, Garro AJ, Lieber CS: Enhanced pulmonary and intestinal activation of procarcinogens and mutagens after chronic ethanol consumption in the rat. Eur J Clin Invest 11:33-38, 1981 